Covic, Boze, ed. 1991. Croatia Between War and Independence. Zagreb: University of Zagreb and Omladinski kulturni centar.

—. 1991. Izvori velikosrpske agresije. Zagreb: August Cesarec \& Skolska knjiga.

Cuic, Stjepan. 1992. Abeceda licemjerja. Zagreb: Prova.

Djuretic, Veselin. 1993. Demolition of Serbs in the 20th Century-Background of the current drame in dismembered Yugoslavia. Belgrade: Serbian Academy of Arts and Sciences, Institute for Balkan Studies.

Dzadzic, Petar. 1991. Nova ustaska drzava? Od Ante Starcevica do Pavelica $i$ Tudjmana (trece dopunjeno izdanje). Beograd: Politika.

Fogelquist, Alan F. 1993. Handbook of Facts on: The Break-Up of Yugoslavia, International Policy, and the War in Bosnia-Hercegovina. Whitmore Lake, Mi.: AEIOU Publishing.

Gow, James. 1992. "Military-Political Affiliations in the Yugoslav Conflict." RFE/RL Research Report, 1:20, pp. 16-25.

Grakalic, Marijan. 1988. Ljubljanski proces-prilog istrazivanju kulture ljudske slobode. Ljubljana: Emonica.

Helsinki Watch. 1992 and 1993. War Crimes in Bosnia-Herzegovina, Vols. I\& II. New York Helsinki Watch

Izetbegovic, Alija. 1990. The Islamic Declaration-A Programme for the Islamization of Muslims and the Muslim Peoples. Sarajevo: n.d.

Jansa, Janez. 1992. Premiki-Nastajanje in obramba slovenske drzave 1988-1992. Ljubljana. Zalozba mladinska knjiga.

Jelcic, Dubravko. 1991. Dnevnik od rujna do rujna 1989-1990. Zagreb: Graficki zavod Hrvatske.

Kadijevic, Veljko. 1993. Moje vidjenje raspadavojska bez drzave. Beograd: Politika.

Kruselj, Zeljko. 1992. "The Yugoslav People's Army: From Liberation to Liquidation." East European Reporter, 5:2, pp. 29-32.

Letica, Slaven. 1992. Obecana zemlja-politicki antimemoari. Zagreb: Globus International.

Molinari, Fulvio. 1992. Jugaslavia dentro la guerra. Gorizia: Editrice goriziana.

Nakarada Radmila, Lidija Basta-Posavec, Slobodan Samardzic. 1991. Raspad Jugoslavije-Produzetak ili kraj agonije. Beograd: Institut za evropske studije.

Raskovic, Jovan. 1990. Luda zemlja. Beograd: Akvarijus.

Roksandic, Drago. 1991. Srbi u Hrvatskoj od 15. stoljeca do nasih dana. Zagreb: Vjesnik.

Smith, Anthony D. 1986. The Ethnic Origins of $\mathrm{Na}$ tions. Oxford: Basil Blackwell.

Strugar, Vlado. 1990. Velika buna Cme Gore 19881989. Beograd-Niksic: Knjizevne novineUniverzitetska rijec.

Separovic, Zvonimir, ed. 1992. Documenta croatica-On Croatian History and Identity and the War Against Croatia. Zagreb: Croatian Society of Victimology.

Soldo, Lidija. 1992. "Zaljubljeni u smrt." NIN, October 9, pp. 28-29.

Tudjman, Franjo. 1992. "Tudjman Discusses Relations with Slovenia." FBIS Daily Report, East כurope, 14 October 1992, pp. 34-37.

\title{
From State Socialism to State Nationalism: The Case of Serbia in Gender Perspective
}

\author{
Zarana Papic
}

A Belgrade journalist once said: "We are living dream of our nationalists that has come true." Modifying his statement it could be argued that in Serbia we are living the dream of state nationalism "our Leader" dreamt of. It is not to say that in Serbia there is "oneman-nationalism," made by one person, nor one could leave out all the other important, historical, cultural factors that led to it. Among those instigators, the most prominent one is the nationalist ideology, dominant and shared among seemingly different, or antagonistic, ideological and political groupings: 1) the great majority of Serbian political (even Leftists) dissidents of Tito's Yugoslavia, 2) the Serbian anti-communist and nationalist literary intelligentsia which found the way to express its feelings only through the "fine arts" of writing, painting, etc., 3) the major opposition parties which emerged later on, and, 4) the new ideology of the converted Communist Party of Serbia ("transformed" into the Socialist Party of Serbia by decree, in one day in 1990), which put the Serbian national(ist) interest above all, but kept the socialist "screen" in order to maintain its former control over the state, media and cultural life.

Slobodan Milosevic is paradoxically or not, a unique and very complex "product" of all these factors and tendencies. $\mathrm{He}$ introduced nationalist mythology, which was the strongest anti-communist legacy of dissident nationalist literary intelligentsia, as the crucial, but neatly veiled substance of his "socialist" ideology. At the same time, while converting the ex-communist party into nationalist-covered-by socialist party, he also introduced, or more precisely, revived totalitarian

Zarana Papic is with the Department of Sociology (Faculty of Philosophy), University of Belgrade. socialist ideology as Stalinist-Bolshevik ideology, which in former Yugoslavia had disappeared long ago, abandoned after Tito's break with Stalin in 1948. The former Yugoslav "way to socialism" in many ways departed from this practice: in liberalization of the market economy, party decentralization, self-management ideology, and openness to the West, to name a few. Although many of former Yugoslavian social, cultural and economical advantages over other Eastern countries may now seem only as a "cunning of the totalitarian communist spirit," which was well hidden in these liberated forms, still it is possible to argue that the former Yugoslavian socialist reality was not, and could not be reduced only to "pure" totalitarian-Soviet-Bolshevik-Stalinist type of legacy.

But, this "post-socialist" conversion of the Serbian Communist Party into the (nationalist) Socialist Party in fact brought back to life the totalitarianBolshevik-Stalinist party ideology and practice. It is important to stress here that at the famous 8th Conference of the Communist Party of Serbia, held in October 1987, Mr. Milosevic successfully defeated the whole bunch of liberal but not nationalist party functionaries, and all those in control of media, culture, education, etc. who were liberal and not nationalist.1 By succeeding in making the "coup de partie;" the leader had the open space and free hand to extend it to the real "coup d'état," as party structure, although in its liberated form, actually dominated and governed all spheres of public life. That is how the liberal form of former Yugoslav socialism in Serbia was transformed (by regression) into a State Socialist regime, which relied dominantly on nationalist ideology and its nationalist "activists," and actually became a mixture of state socialism and state nationalism. 
The reason why "our leader" is the "right" person to have this above mentioned nationalists' dream come true is the fact that he actually embodies both regimes: the State Socialist one which was dear to him in his "aparatchik" past, and the State $\mathrm{Na-}$ tionalist one which is now his "Czarist" present. And, also, due to the effects of his "transformation" of former (one of the more liberal) Communist Party of Serbia into state-socialist-plus-nationalist regime, we are now living in a state nationalism which is a twin, a duplicate of state socialism. As a matter of fact, under Milosevic's reign one can easily find the fundamental elements of state nationalism-so similar to those of state socialism-only under different names. Table 1 shows a list of parallel elements essential to both state socialism and state nationalism, by answering a few questions:

As we can see, both in Serbia's State Socialist past and State Nationalist present we did not, and do not, have a civic definition of the citizen, but only the narrow, ideologically and instrumentally defined one.

Keeping in mind these rather apparent similarities between state socialism and state nationalism in Serbia it is possible to stress two points: first, that nationalist ideology in Serbia has been introduced and established within, and on the basis of previous Communist Party ideology, structure, character of leadership, the obedience demanded of its members, etc.; second, that Serbian state nationalism, just as state socialism had been, was

\section{Table 1: State Socialism vs. State Nationalism}

What do we have in State nationalism? The leader of the nation.

Who are the subjects?

The mass of "true" Serbian people.

Who are ideologically correct people?

Faithful, obedient to the great national cause, and to the "line" of the great

What is the struggle against? Inside traitors of "true" Serbianhood.

Who is the enemy?

The enemies of the nation-other nations, and inside traitors.

What is the goal of State nationalism? All Serbs in one country.

When will this goal be achieved? In heaven, because Serbs as such are "heavenly people."

And what about the categories of person and citizen?

What did we have then, and what do we have now?

The bad person: non-Communist or anti-communist.

True" citizen: Mr. and Mrs. Communist.
In state nationalism we have:

The good person: Mr. and Mrs. Good

Serbian, faithful to "true" Serbianhood.

The bad person: "bad" Serbians, traitors of "true" Serbianhood.

"True" citizen: Mr. and Mrs. Serbian. brought from above, as the "official" policy, and highly recommended "party" line.

In that sense one could argue that Serbian nationalism in fact was not, and is not, grassroots nationalism, but nationalism "activated" and "born" from above. That would be, in my opinion, only one side of the matter. The basis for Serbian nationalism, of course, did exist among anti-communist nationalist dissidents, as I outlined at the beginning of this text, and in a significant manner it actually prepared Milosevic's rise to power. But, when nationalism became a part of the official ideology, it was then further intentionally provoked, instrumentally constructed, programmed, cemented, and with constant media propaganda even forced upon people.
Therefore, Serbian nationalism has its very specific features. It did start long ago as the oppositional, nationalist ". alternative" to communism, butthanks to Mr. Milosevic's sudden "conversion" from communism into nationalism-became amalgamated with the previous (maintained intact) Party structure. Instead of communist ideology, the newly born Socialist Party ideology was then thoroughly, sometimes even brutally, permeated with aggressive and officially sanctioned nationalism.

But, one could rightly ask how did all this come to be possible? First, of all, in the East, socialism lost almost all credibility as a social project for a "just" society. Due to the exclusive and unhappy experience of socialism as totalitarianism in Eastern and Central 
Europe, the swing of social processes is now going into another extreme direction-toward the conservative, traditional, nationalist, patriarchal and simple minded concept of democracy. Eastern countries are now going through painful (and dangerous: the best example is Yugoslavia) processes of liberation of many suppressed dimensions, which had been forbidden or restricted under socialism. These suppressed dimensions are complex and, as a rule, they are double-faced, containing at the same time, normal and extreme shapes such as: national in the extreme shape of aggressive nationalism, religious identity as extreme fundamentalist inclination, liberal understood only as anti-communist, democratic as primarily anti-Socialist, etc. Frequently these new ideologies, in which nationalism is predominant, represent, in fact, a reversed mirror of the ex-socialist style. These new democracies and ideologies are as authoritarian, rigid, intolerant of any difference, and totalitarian as socialism itself-its great enemy-had been.

That is why, it seems to me, it is important to reverse the prevailing opinion and perspective of past socialist realities. The real issue is not what the totalitarian socialist regime had done, but quite the opposite-what this regime had not done. The question is not purely rhetorical, because the way one posits the critical perspective on the experience of the socialist past is the crucial factor leading to possible ways of seeing and recognizing its alternatives. It simply means that any (anticommunist) alternative to totalitarian communism does not necessarily have to be a democratic one. Of course, no one is denying that totalitarian socialist regimes did suppress and oppress all the "antisocialist" tendencies: democratic as "bourgeois," religious, national, ethnic, cultural, historical, etc. But, more important is the fact that socialism did not in any way help $t u$ build the complex social fabric which could serve as the basis for democratic alternatives. With such totalitarian practices, socialism consequently prevented the rise and growth of the con- ditions necessary for the construction of the democratic character of people.

Because of that, the collapse of communism resulted in an opening of the dangerous (deadly dangerous in the case of former Yugoslavia) civic voidthe absence of democratic substances, values, institutions, patters of behaviour, etc., as the possible means and criteria for the way out of the totalitarian order. We are simply, faced with the fact that we want to change the totalitarian East into "new democracies" with unchanged people, whose personality structure is far from being democratically oriented. So, due to the opening of this kind of civic void it was possible for all sorts of overt undemocratic "alternatives" to find their place, and in which aggressive nationalism and chauvinism found perfect soil to grow.

The most striking example of this civic void which was filled with antidemocratic "solutions" is the case of former Yugoslavia. Because of its multinational multi-ethnic structure post-ex-Yugoslavia witnessed enormous growth of nationalisms and chauvinisms. The very specific feature of Yugoslavia, which to many of us seemed (naively?) as a richness of possibilities-its multinational and multiethnic structure-is now used (that is, abused ) as the perfect instrument of hatred, the constant reason for and cause of war, and the main obstacle to democratization. Instead of having a plurality of, previously suppressed cultural, historical and national democratic solutions for such a multi-ethnic and multicultural country, as ex-Yugoslavia was-we are now facing, and terribly suffering from an aggressive plurality of nationalisms and chauvinisms of nations which have no mercy for anything, such as cities, or for anybody, such as innocent people whose only fault is that they happen to live where guns are firing. Now, every nation is losing its dignity committing unimaginable atrocities against the other enemy nation. But, aside from all previous or "historical" reasons, no one can deny the fact that Serbs, not at all in their own interest (but precisely the opposite), pulled the trigger, and started this tragic and disastrous "game."

The effects of this nationalist pluralization are, in fact, non-pluralist at all. Although there are many surface differences between new states-this non-pluralist element is their common denominator. The reason this is so lies in the very concept of the (postsocialist) political transformation, advocated by the majority of new post-communist political parties. The strongest (and winning) parties, in particular, in republics or new states, had in their programmes and objectives the extreme expression of nationalist ideologies. They were as nationalist and exclusive of other national identities, as much as they were traditional, militant, patriarchal, sexist, in their programmes, types of organization, their symbolic order, language, accents, omissions and blind-spots, etc.

Briefly, the main problem and the most tragic result of the disintegration of former Yugoslavia is the dominant, manipulative operation of purposefully provoking, constructing, and "producing" nationalisms and chauvinisms-mythological, narcissistic, non-reflexive, aggressive, hateful towards other nations, as the main and only guilty party for its sufferings and "historical losses." For the ruling parties, the nation is above everything, above every ideology. It is above every possibility of diverse political orientations within the very same nationwhich are an obvious and necessary precondition of democracy. Nation is, therefore, above democracy.

The aim is not to equalize and flatten all nationalisms (because they assume different forms according to historical and cultural backgrounds, and different ways of expression), nor to negate the values of affirming emerging national and confessional values and identities, which were deeply suppressed in socialism. What I am trying to say is that when the chance of democratic national emancipation loses or abandons its tolerant and multi-ethnic possibility (being in- 
stead aggressive and revengeful), it becomes deadly dangerous in fanatic hate of other nations as the eternal historical enemy, as the target on which all aggression is focused. Now we can see that it is above every human life, or any other decent human interest.

Moreover, with media-war-propaganda (going on endlessly, "bombing" people's minds every night), each side produces its "reality" - a modified and instrumentally adapted truth. In such a divided country in which travelling is no longer possible, not to mention security of existence and residence in one's own home, media-manipuláted messages of these closed "entities" cuts the truth in order to prove one point-that "We," our nation, and "our Cause" for war is so justified that there should not be any doubt in the "heavenly" 2 righteousness of "our" eternal historical rights and in the war in defence of them.

With this totalitarian domination of nationalist ideologies the first and

the Serbian leader once clearly put it. Nation is, accordingly, and undoubtedly, above democracy. Democracy is the traitor of the nation, because it brings with it "disunion," and questions the "rightness" and "rationality" of its goals and means.

Furthermore, one of the most pertinent features of all these new postCommunist democracies is the fact that they are male dominated, overtly patriarchal, traditional, and conservative regarding the position of women, their social role and significance. In the Eastern former socialist countries the new patriarchy is now the prevailing social reality for women, as well as for men. This is also the result of the above mentioned civic void left by the collapse of communism. The socialist regime was a communist, and male dominated, patriarchal, and authoritarian conglomerate which, paradoxically was stabilized even more by the mixture of progressive women's legal rights, and existent patriarchy that

\section{...One of the most pertinent features of all these new post-Commu- nist democracies is the fact that they are male dominated, overtly patriarchal, traditional, and conservative regarding the position of women, their social role and significance.}

greatest victim is civil (even ex-socialist) society itself, which is always expendable when nationalist interest demands it. With civil society in danger, all human rights are in danger. They are rights on paper only, deactivated rights serving only as a nationalist smokescreen in front of Western democratic eyes. The real, effective and activated rights are now something else: they are mythological rights that glorify the old heroic and tragic national destiny; they are a historical in their obstinate revival of (past) "historical claims," unscrupulously applied to different, present-day circumstances.

Moreover, the "saint" of national interest demands unity, it cannot accept dialogue, and does not tolerate difference(s). It approves only of the collective mind and national "truth" because the "nation is always right," as governed women's real lives. With fifty years of "socialist emancipation" behind them, women never learned to take the active, self-conscious part in facing and confronting the new political, ex-socialist, reality. Instead, they were actually very well prepared to be and stay passive in the new processes of political and democratic transformations. Before their very eyes, the new patriarchy emerged, because the whole concept of the emancipation of women and equality between the sexes simply vanished as the significant and equal component of these new democracies.

In that sense, as all these new democracies are in fact deeply male democracies, all these newly emerged post-communist nationalisms are also male nationalisms. Their essential discourse, and practice, is that of the warrior, the "hero" of nationhood is no one else but a Man, who is defending the nation, territory, tradition, glory, honour, etc. This type of aggressive, waroriented nationalism, as a rule, is based and functions on a patriarchal system of values and social, gendered order, in which men and women are separated into opposite zones-(battle) fields and (sheltered) fields. This kind of war-gendered-order is the most extreme example of men's and women's separated realities, which are presented and seen as a natural, unavoidable and eternal state of affairs.

In fact, one could argue that every nationalism is male nationalism. The relationship between nationalism and women is contradictory, paradoxical and, as a rule, a mystified one. The contradiction lies in the fact that all nationalist basic values, goals and myths are "feminine" - in Serbian, as in many languages, nation, motherland, tradition, honour, glory, history, etc. are of female gender. Moreover, women are of fundamental importance as actual "producers" and pillars of all these values and goals. But the problem is that there is no way women could be, or become, equal partners and subjects of these values. Instead, they are objects, consequently objectified in their prime function of reproducing the very same "feminine" values, but from which they are excluded.

Attention is focused on Serbian nationalism for two reasons. First, this is the nationalism I have lived with and through, all these years. Second, because I frankly believe that everyone has to confront and criticize primarily one's own nationalism in order to understand, and then, perhaps to criticize others. The specificity of Serbian aggressive nationalism is that it is so deeply patriarchal in its "essence" that, paradoxically, it does not even have to articulate, accentuate or to prove itself by open control over women. Serbian patriarchal ideology is a warrior's mythology in which the place for women is clearly and strictly defined-women are there because of men, they are in their function as breeders of new generations of brave soldiers. There are many examples in 
Serbian mythology of women dignified exclusively as mothers of sons who went to fight, and were killed, for their national pride.

This tribalist patriarchalism indisputably put women into their submissive role of mothers, wives and caretakers of children in refuge. Some of them identify themselves with the great cause and they take part in battles, shootings and a military way of life. They are accepted as such, as equal warriors and they are media stars, of course. But, the most evident fact is that in these nationalist-war circumstances, women are completely unimportant and invisible, except in their role as mothers and wives. They are not seen or heard as possible subjects who have the right to speak their minds, or to have a voice in these matters. The war is men's world. But its victims are mostly women and children.

There is yet another possible explanation why men, actively motivated to fight to death, are so dominantly visible, and women are so invisible, almost nonexistent in all these terrible and brutal killings and media war propaganda. The main (but hidden) reason why nationalist propaganda is exclusively focused and oriented toward men is again a paradoxical one: during fifty years of peace, the Serbian traditional (patriarchal) masculine identity has, in fact, deeply changed, under the influence of civilizing and urbanizing transformations, and has become more complex, tolerant, urban-like "softer," and less eager (or, not even interested) to simply go and fight with Croats, and later with Muslims--to revenge for all the past tragic losses. So, that is why the war-hostility-propaganda is so boringly obstinent, repetitious (very effective), aggressively truthful in its open manipulation, invoking and reviving the good old warrior's masculinity-as the defender of its nation, its territory, home, family.

Media-war-propaganda is primarily oriented toward the deconstruction of the present (or, more precisely, already past and gone) urban, cul- tured, civilized and less aggressive prewar type of masculinity, and, at the same time, toward the reconstruction of the previous, older (but in nationalist mythologies the only "true") aggressive, abusive, "manly," "brave" militant masculinity which will obediently follow the nation's causes and calls for battle.

But in this programmed operation of reviving the old, patriarchal "order of things," all the cynicism of nationalist manipulation of basic, historical human standards and values becomes clear. This newly-constructed patriarchal order-"invented tradition" (hobsbawm)-is nothing but a surrogate for, and is by no means the same as the (historical) old Serbian patriarchal order. Because, in former times, the patriarchal order preserved basic values of dignity, and its type of masculinity was not sadistically violent, nor immorally prone to bestiality.

This type was warrior-like, but not of this ominous kind. It was strictly and morally controlled against dehumanization, dignified in its principles, as well as in its reasons for war. That is also the reason why the present "emancipation" of previously suppressed national and confessional identities is not oriented toward recreating and rehabilitating its cultural values, morals and genuine religious humanity. On the contrary, it is oriented toward the annihilation of all those values, because they are "nonfunctional" in making nations and Confessions hate and kill each other.

This leads to another dimension of state nationalism, than of its twin, state socialism. That is the fact that state nationalism is even more totalitarian than state socialism used to be. For instance, the categories of "traitor" and "enemy" in State socialism were applied to those considered non-Communist or anti-communist. This label, however threatening and repressive it might have been, actually was a political category, leaving at least some, although very little, space for personal identity ineducable to such political stigmatization. But in state nationalism, the totalitarian concept of nation- hood penetrates and every aspect of our being. It enters our birth certificate-the first document of our personal existence and individuality. It leaves us no free space for our personal articulation, or choice. We become what is written in our birth certificate, as the inescapable part of our identities, by the simple fact that we are born somewhere (territory), and to someone (national identity). This is totalitarian (very total, indeed) nationalist occupation of the total space of our identities. We cannot escape it. By this cunning operation we are forever what we can never choose-our predetermined origin, blood and nation.

Therefore, categories such as the "traitor," and the "enemy" in nationalism are no longer a political category, but an overall category that pretends to be the one and only definition of our humanity. So, being a traitor of "true" Serbianhood is an even more dangerous and much deeper stigmatization. Due to this totalitarian nationalist domination of our whole human substance, being labelled as a traitor of "true". Serbianhood means actually being a "traitor" to humanity itself, as it is so defined. There is no possibility to choose to be different, but only the "true" (aggressively nationalist) Serbian. In this, there is no plurality, no choice. They have chosen instead of us. 1

\section{Notes}

1. The very term "cleansing" actually belongs to the communist vocabulary. Therefore, one could say that the ideological cleansing of all those who were near the power and who did not adapt themselves to extreme Serbian nationalist ideology and mythology, was the essential precondition for later deadly practice of ethnic cleansing.

2. The heavenly element is very important in the Serbian mythological nation's identity. After the lost battle with Turks at Kosovo six hundred years ago (1389), the myth has been made that Serbs, by losing this crucial Battle, gained their place in heaven, and therefore, became a heavenly nation, exceptional and fundamentally different from all other nations. This mythological element is very often used as a primary criterion for Serbs' (heavenly) superiority over all other national identities. $\square$ 